\section{Economic Evaluation of Implementing Strawberry Season Extension Production Technologies in the U.S. Intermountain West}

\author{
Tiffany L. Maughan \\ Department of Plants, Soils and Climate, 4820 Old Main Hill, Utah State \\ University, Logan, UT 84322
}

Kynda R. Curtis ${ }^{1}$

Department of Applied Economics, 4835 Old Main Hill, Utah State University, Logan, UT 84322

\author{
Brent L. Black and Daniel T. Drost \\ Department of Plants, Soils and Climate, 4820 Old Main Hill, Utah State \\ University, Logan, UT 84322
}

Additional index words. economic feasibility, high tunnels, low tunnels, supplemental heating, Fragaria Xananassa

\begin{abstract}
Strawberry production in the U.S. Intermountain West is limited by harsh climatic conditions and competition from domestic producers and imports. Using season extension methods to combat climatic conditions may be effective but generally increases production costs. This study evaluates the economic returns to implementing high tunnels, low tunnels, and in-ground supplemental heating to strawberry production (Seascape and Chandler cultivars) in northern Utah. The high tunnel provided a net return of $\$ 1,943.57$ or $\$ 15,548.56$ per hectare assuming eight high tunnels per hectare. The addition of low tunnels within the high tunnel led to a positive increase in net returns for 'Seascape' but not for 'Chandler' production. Supplemental in-ground heating increased net returns by up to $\mathbf{5 0 \%}$ for both cultivars, primarily as a result of higher preseason yield and market pricing. Study results find that season extension technologies can successfully increase net returns to strawberry production through early and increased yields, when strawberries are sold primarily through local direct markets.
\end{abstract}

Fruit growers in the U.S. Intermountain West (the region including the states of Montana, Utah, Idaho, Wyoming, and Colorado) are faced with several challenges including decreased agricultural land availability, harsh climatic conditions, and significant competition from both domestic production and imports. Overcoming these challenges is important to maintaining the long-term viability of fruit production in the region as well as sustaining land in agricultural use.

Agricultural land in the Intermountain West has steadily declined as populations have expanded. For example, in Utah only $2.3 \%$ of the state is devoted to irrigated agriculture (Hutson et al., 2005) and only

Received for publication 3 Oct. 2014. Accepted for publication 31 Dec. 2014.

This project is funded in part by the Utah Department of Agriculture and Food under a specialty crop block grant, Utah State University Extension, and the Utah Agricultural Experiment Station, Utah State University, and approved as journal paper number 8715 .

This paper is a portion of a MS thesis submitted by T. Maughan.

${ }^{1}$ To whom reprint requests should be addressed; e-mailkynda.curtis@usu.edu. a small portion of irrigated agriculture is dedicated to fruit production. Utah's population has grown steadily at an average annual rate of $2.48 \%$. As population has increased, prime fruit-growing acreage has been lost to urban and suburban growth, pushing Utah to become a net importer of most fruits (Ernst et al., 2012).

However, as urban development encroaches on agricultural land, farms are often in close proximity to high population centers, which provide the opportunity for direct-toconsumer sales. The growing "Buy Local" movement has created a market of consumers interested in buying local products at premium prices year-round (Curtis, 2014; Martinez et al., 2010). For example, between 1992 and 2007, local food sales grew three times faster in the Far West and Rocky Mountain regions than in other areas of the United States (Low and Vogel, 2011). Nationally, the number of farmers' markets increased by $76 \%$ between 2008 and 2014 (U.S. Department of Agriculture: Agricultural Marketing Service, 2014). Fruit producers have the opportunity to increase production to meet this demand. Ideally, growers could produce year-round to provide a constant supply to the consumer. However, as a result of climatic challenges, year-round fresh fruit production is often cost-prohibitive and requires use of additional technology.

Climate is a major challenge to fruit production in the Intermountain West, limiting both the type of fruit crops grown and the length of the growing season. Fruit production is limited in many areas of the region as a result of high elevation and arid climate conditions, resulting in late spring and early fall frosts as well as large diurnal temperature fluctuations during spring and fall. Additionally, the region's arid and semiarid conditions limit water availability. Finding ways to combat these climatic challenges may increase season length, yields, and, hence, profitability for the region's fruit producers.

Finally, both domestic and import competition limits the financial success of Intermountain West fruit growers as a result of low product pricing, especially during the region's primary growing season. Other fruitproducing regions of the United States and overseas do not have the climatic challenges Intermountain West growers are faced with; they are able to sell their products at lower wholesale prices. Additionally, the increased ability to ship produce long distances provides a year-round supply of fresh fruits at lower market prices.

\section{Fresh Strawberry Market}

The production window for field-grown strawberries in the northern Intermountain West extends from late May to early July. This period directly overlaps peak domestic production (California and Oregon) and the lowest annual wholesale strawberry prices of $\approx \$ 1.63 / \mathrm{kg}$ (Naeve, 2014). Average monthly fresh strawberry prices are often highest in December as was the case in 2012 when the average wholesale price was $\$ 4.89 / \mathrm{kg}$ (a $200 \%$ increase over the July price), when only Florida strawberries and imports from Mexico were available (Wu et al., 2012). These pricing differences, combined with year-round consumer demand, create the need for extended fruit production into the off season. The climatic conditions in the Intermountain West require the use of season

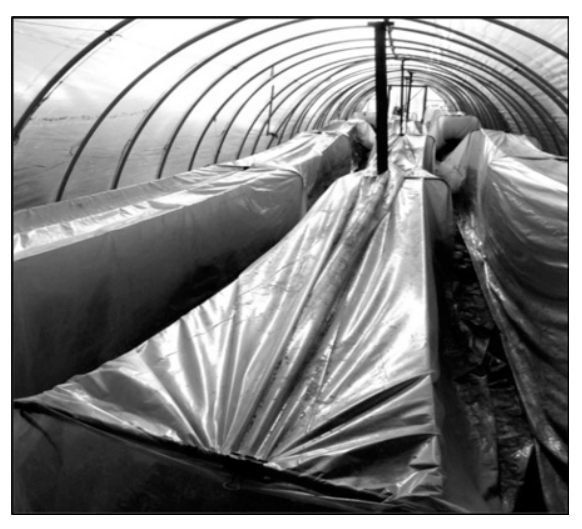

Fig. 1. Low tunnels inside a high tunnel. 
Table 1. High tunnel June-bearing strawberry cost and returns $(4.3 \mathrm{~m} \times 29$-m tunnel $)$

\begin{tabular}{|c|c|c|c|c|}
\hline & \multirow[b]{2}{*}{ Units } & \multicolumn{3}{|c|}{ 1- to 29-m tunnel } \\
\hline & & Quantity & Price & Total \\
\hline \multicolumn{5}{|l|}{ Revenues } \\
\hline Early out-of season strawberries & $1 \mathrm{~kg}$ & 169.6 & $\$ 13.20$ & $\$ 2,238.72$ \\
\hline In-season strawberries & $1 \mathrm{~kg}$ & 214.4 & $\$ 9.90$ & $\$ 2,122.56$ \\
\hline Total revenues & & & & $\overline{\$ 4,361.28}$ \\
\hline \multicolumn{5}{|l|}{ Operating expenses } \\
\hline \multicolumn{5}{|l|}{ Supplies } \\
\hline \multicolumn{5}{|l|}{ Preplant and preparation costs } \\
\hline Soil test & Each & 1 & $\$ 14.00$ & $\$ 14.00$ \\
\hline Fuel & $\mathrm{L}$ & 1.5 & $\$ 3.50$ & $\$ 1.31$ \\
\hline Fertilizers and soil amendments & $\mathrm{kg}$ & 1 & $\$ 15.00$ & $\$ 33.75$ \\
\hline Plastic mulch & $\mathrm{m}$ & 85 & $\$ 0.05$ & $\$ 14.06$ \\
\hline Drip tape & $\mathrm{m}$ & 175 & $\$ 0.05$ & $\$ 28.80$ \\
\hline \multicolumn{5}{|l|}{ Strawberry establishment and growth } \\
\hline Plug plants & Each & 743 & $\$ 0.26$ & $\$ 193.05$ \\
\hline $20-20-20$ water-soluble fertilizer & $\mathrm{kg}$ & 5.1 & $\$ 1.23$ & $\$ 13.95$ \\
\hline 10-30-20 water-soluble fertilizer & $\mathrm{kg}$ & 1.3 & $\$ 1.49$ & $\$ 4.22$ \\
\hline Captan & $\mathrm{kg}$ & 0.2 & $\$ 9.82$ & $\$ 4.20$ \\
\hline Thionex $50 \mathrm{~W}$ & $\mathrm{~kg}$ & 0.01 & $\$ 7.51$ & $\$ 0.20$ \\
\hline \multicolumn{5}{|l|}{ Strawberry harvest } \\
\hline $0.5-\mathrm{kg}$ clamshells & Each & 1,033 & $\$ 0.25$ & $\$ 258.19$ \\
\hline Total supplies & & & & $\$ 565.73$ \\
\hline \multicolumn{5}{|l|}{ Labor } \\
\hline \multicolumn{5}{|l|}{ Preplant and preparation costs } \\
\hline Soil test & Hours & 0.5 & $\$ 10.00$ & $\$ 5.00$ \\
\hline Apply preplant fertilizers & Hours & 0.75 & $\$ 10.00$ & $\$ 7.50$ \\
\hline Tillage & Hours & 7.5 & $\$ 10.00$ & $\$ 75.00$ \\
\hline Form raised beds & Hours & 13 & $\$ 10.00$ & $\$ 130.00$ \\
\hline Install drip tape & Hours & 0.75 & $\$ 10.00$ & $\$ 7.50$ \\
\hline Cover with plastic mulch & Hours & 1 & $\$ 10.00$ & $\$ 10.00$ \\
\hline \multicolumn{5}{|l|}{ Strawberry establishment and growth } \\
\hline Planting labor & Hours & 6 & $\$ 10.00$ & $\$ 60.00$ \\
\hline Fertigation & Hours & 2 & $\$ 10.00$ & $\$ 20.00$ \\
\hline Pesticide applications & Hours & 4.5 & $\$ 10.00$ & $\$ 45.00$ \\
\hline Hand weeding & Hours & 4 & $\$ 10.00$ & $\$ 40.00$ \\
\hline Coverings install/removal & Hours & 12 & $\$ 10.00$ & $\$ 120.00$ \\
\hline Monitoring and ventilation & Hours & 30 & $\$ 10.00$ & $\$ 300.00$ \\
\hline \multicolumn{5}{|l|}{ Strawberry harvest } \\
\hline Hand harvest & Hours & 68 & $\$ 10.00$ & $\$ 680.00$ \\
\hline \multicolumn{5}{|l|}{ Postharvest } \\
\hline House clean out & Hours & 4.5 & $\$ 10.00$ & $\$ 45.00$ \\
\hline Total labor & & & & $\$ 1,545.00$ \\
\hline Total operating expenses (supplies and & & & & $\overline{\$ 2,110.73}$ \\
\hline \multicolumn{5}{|l|}{ Fixed expenses (depreciation) } \\
\hline High tunnel annual & & & & $\$ 248.17$ \\
\hline Irrigation system annual & & & & $\$ 58.82$ \\
\hline Total fixed expenses & & & & $\$ 306.98$ \\
\hline Total expenses & & & & $\$ 2,417.71$ \\
\hline Net income & & & & $\$ 1,943.57$ \\
\hline
\end{tabular}

Net income extension technologies so that growers may successfully supply markets for longer periods of time. Additionally, it is important for growers, especially those with small acreage, to sell at least a portion of their product through direct local markets such as farmers' markets, community-supported agriculture programs, or roadside stands to avoid competing with lower wholesale prices (Gunter et al., 2012; Yeager, 2013). Consumers are willing to pay price premiums for local foods at direct markets, especially when available outside of the normal season, providing growers the opportunity to garner higher prices (Curtis, 2014; Curtis et al., 2014; Foord, 2004). However, the type of direct marketing method(s) used affects the marketing costs. Thus, labor, transportation, and packaging cost as well as potential vendor fees should be considered.

Although current strawberry production in the Intermountain West is minimal (too low to justify USDA reporting), consumption of fresh strawberries in the United States rose dramatically from 1998 to 2012 as per-capita consumption went from $1.77 \mathrm{~kg} /$ year to 3.54 $\mathrm{kg} /$ year (U.S. Department of Agriculture: Economic Research Service, 2012). The increased consumer awareness of the health benefits of strawberries, including folate, potassium, vitamin $\mathrm{C}$, fiber, and antioxidant levels, stimulated domestic consumption (Naeve, 2014). Assuming consumption in Utah is comparable to national averages, strawberry growers would need to produce $\approx 9.9$ million kilograms of strawberries per year (328 kg per week) to meet local demand. Assuming the field production season is $\approx 6$ weeks, and that per-capita consumption remains relatively constant throughout the year, a conservative estimate for local strawberries would be 1.1 million kilograms during the peak season. Of course, it is likely that consumption varies seasonally, making this a relatively conservative estimate of local demand.

\section{Fresh Strawberry Production in the Intermountain West}

In temperate-zone strawberry production, temperature is one of the most important limiting factors with ideal temperatures for strawberry growth being between 20 and $26{ }^{\circ} \mathrm{C}$ (Darrow and Waldo, 1934). Growth of many crop and plants responds predictably to temperature. This relationship is defined by critical minimum, optimum, and maximum temperatures. For strawberry, the minimum critical temperature is just above freezing (Galletta and Himmelrick, 1990) with growth rates increasing as the temperature increases. Although there is some variation resulting from acclimation and cultivar differences, generally maximum growth rates occur at $22{ }^{\circ} \mathrm{C}$ and then steeply decrease as temperatures approach the maximum limit for growth. Growth slows dramatically at $29{ }^{\circ} \mathrm{C}$ with damage occurring above $35^{\circ} \mathrm{C}$ (Arney, 1953; Carlen et al., 2009). Temperatures in 
Table 2. Annual depreciation for high tunnel and irrigation system

\begin{tabular}{llcrrr}
\hline & Units & Years of use & Quantity & Price & Total \\
\hline High tunnel & & & & & \\
$\quad$ High tunnel & Each & 6 & 1 & $\$ 497.00$ & $\$ 497.00$ \\
Initial construction labor & Hours & 6 & 25 & $\$ 10.00$ & $\$ 250.00$ \\
6-mil greenhouse film & $7.3 \mathrm{~m} \times 30.5 \mathrm{~m}$ & 3 & 2 & $\$ 221.00$ & $\$ 442.00$ \\
Shadecloth & $6 \mathrm{~m} \times 30.5 \mathrm{~m}$ & 6 & 1 & $\$ 300.00$ & $\$ 300.00$ \\
$\quad$ High tunnel total & & & & & $\$ 1,489.00$
\end{tabular}

Annual depreciation cost of high tunnel

$\$ 248.17$

$\begin{array}{ll}\text { Irrigation system } & \\ \text { 1.9-cm polyethylene pipe } & \text { Foot } \\ 2.5-\mathrm{cm} \text { valve } & \text { Each } \\ \text { Miscellaneous fittings } & \text { Each } \\ \text { Drip hose adapter } & \text { Each } \\ \text { Injector } & \text { Each } \\ \text { Filter } & \text { Each } \\ \text { Pressure regulator } & \text { Each } \\ \text { Installation labor } & \text { Hours } \\ \quad \text { Irrigation system total } & \end{array}$

Annual depreciation cost of irrigation system either no fruit will form or misshapen, unmarketable fruit develop. Primary flowers are the first to open on the inflorescence and therefore are often the blossoms that are damaged. Primary flowers have the potential to produce larger fruit than secondary and tertiary flowers. Boyce et al. (1985) found that when primary blossoms were removed, no weight compensation was made by remaining fruit. Thus, loss of primary blossoms resulted in a $30 \%$ decrease in overall yield because the secondary and tertiary flowers did not compensate for the loss of yield from primary flowers. During bloom, spring frosts are common in the region. Thus, temperature modifications are needed to protect these first blossoms to realize full yield potential. There are several methods used for manipulating growing temperatures to stay within the optimum temperature range. Some notable methods are high tunnels, low tunnels, floating rowcovers, and soil heating.

High tunnels operate and look like greenhouses but are passively heated and cooled, which significantly reduce operating costs as compared with greenhouses. They are temporary structures constructed with either galvanized steel or polyvinyl chloride pipe framing and covered with greenhouse-grade plastic. High tunnels are heated through shortwave radiation from the sun that enters the high tunnel and is absorbed by the soil and plants. The plastic traps the heat that dissipates from the covered plants and soil in the form of conduction and convection as well as emitted long wave radiation and the tunnel air temperature increases. This can result in as much as a $30{ }^{\circ} \mathrm{C}$ increase in air temperature above the ambient outside air temperature during the day (Wien et al., 2008). Much of the accumulated heat dissipates after the sun sets, but the air within the high tunnels can still remain 1 to $3{ }^{\circ} \mathrm{C}$ warmer than the surrounding environment during the night. The daily temperature increase extends the growing season earlier into the spring and later in the fall. Areas where the growing season is limited by extreme diurnal temperature fluctuations are particularly well suited for high tunnel use because energy accumulated during the day can maintain tunnel temperatures above freezing during the night. The high-elevation arid valleys of the Intermountain West are particularly prone to these spring and fall temperature fluctuations. In the Intermountain West, high tunnels can effectively extend the growing season for strawberries by 4 to 6 weeks, making commercial production economically viable through higher pricing in the extended season (Hancock and Simpson, 1995) and through higher yields by protecting blossoms from spring frosts (Rowley, 2010).

Low tunnels or rowcovers can also be used to increase temperature around the plant. Rowcovers are placed directly on top of plants without any support structure. Low tunnels are much smaller than high tunnels, usually only large enough to cover the strawberry bed and plant canopy. Clear plastic is suspended over plants using either sturdy
Utah meet the ideal growing conditions for only a short period each year, being either suboptimal or superoptimal for most of the year.
Blossoms are susceptible to damage at temperatures below $-1{ }^{\circ} \mathrm{C}$ (Hummel and Moore, 1997; Maas, 1998). Depending on the extent of injury and stage of development, 
Table 5. Total strawberry yields per production system, 2012.

\begin{tabular}{llc}
\hline & & $\begin{array}{c}\text { Plug } \\
(\mathrm{kg} / \mathrm{plant})\end{array}$ \\
\hline Chandler & High tunnel only & $0.77 \mathrm{a}^{\mathrm{z}}$ \\
& High tunnel + low tunnel & $0.63 \mathrm{~b}$ \\
& $7{ }^{\circ} \mathrm{C}+$ high tunnel + low tunnel & $0.90 \mathrm{a}$ \\
& $15^{\circ} \mathrm{C}+$ high tunnel + low tunnel & $0.93 \mathrm{a}$ \\
& & $0.49 \mathrm{c}$ \\
Seascape & High tunnel only & $0.71 \mathrm{~b}$ \\
& High tunnel + low tunnel & $0.59 \mathrm{~b}$ \\
& $7{ }^{\circ} \mathrm{C}+$ high tunnel + low tunnel & $0.63 \mathrm{~b}$
\end{tabular}

Analysis of variance

$P$

Treatment

0.005

Cultivar

${ }^{\mathrm{z} N u m b e r s}$ within a column followed by same letter are not significantly different at $P \leq 0.05$.

Table 6. Comparison of supplemental root zone heating at 7 and $15^{\circ} \mathrm{C}$ on 'Chandler' strawberry.

Partial budget comparing 'Chandler' high tunnel + low tunnel strawberry production with and without the use of $7{ }^{\circ} \mathrm{C}$ supplemental heating

Revenues

Unheated high tunnel

Early strawberries $(169.6 \mathrm{~kg}$ at $\$ 13.20 / \mathrm{kg}$ )

In-season strawberries $(214.4 \mathrm{~kg}$ at $\$ 9.90 / \mathrm{kg})$

Unheated total

Heated high tunnel + low tunnel

Early strawberries $(239 \mathrm{~kg}$ at $\$ 13.20 / \mathrm{kg}$ )

In-season strawberries $(259.4 \mathrm{~kg}$ at $\$ 9.90 / \mathrm{kg}$ )

Heating total

Costs

Added costs of low tunnel ${ }^{\mathrm{z}}$

Added costs of heating material ${ }^{\mathrm{z}}$

Resulting change in net income

Difference in revenue

Difference in costs

$\$ 2,238.72$

$\$ 2,122.56$

$\$ 4,361.28$

$\$ 3,154.80$

$\$ 2,568.06$

$\$ 5,722.86$

$\$ 192.47$

$\$ 228.79$

$\$ 1,361.58$

$\$(421.26)$

$\$ 940.32$

Total change

Partial budget comparing 'Chandler' high tunnel + low tunnel strawberry production with and without the use of $15^{\circ} \mathrm{C}$ supplemental heating

Revenues

Unheated high tunnel

Early strawberries $(169.6 \mathrm{~kg}$ at $\$ 13.20 / \mathrm{kg})$

In-season strawberries $(214.4 \mathrm{~kg}$ at $\$ 9.90 / \mathrm{kg}$

Unheated total

Heated high tunnel + low tunnel

Early strawberries $(272.7 \mathrm{~kg}$ at $\$ 13.20 / \mathrm{kg})$

In-season strawberries $(238.4 \mathrm{~kg}$ at $\$ 9.90 / \mathrm{kg}$ )

Heating total

Costs

Added costs of low tunnel ${ }^{\mathrm{z}}$

Added costs of heating material ${ }^{\mathrm{z}}$

Resulting change in net income

Difference in revenue

Difference in costs

$\$ 2,238.72$

$\$ 2,122.56$

$\$ 4,361.28$

$\$ 3,599.64$

$\$ 2,360.16$

$\$ 5,959.80$

$\$ 192.47$

$\$ 332.95$

$\$ 1,598.52$

$\$(525.42)$

Total change

$\$ 1,073.10$

${ }^{\mathrm{z}}$ See Table 8 for breakdown of material costs.

wire or pipe. Low tunnels in conjunction with a high tunnel (Fig. 1) can provide an additional 3 to $5{ }^{\circ} \mathrm{C}$ increase in night temperature (Wien et al., 2008). Temperature elevation during the day is also significantly higher depending on light levels. When low tunnels were used in conjunction with high tunnels, an additional 2 weeks of production were added to the already extended production season (Maughan, 2013).

A third option is to provide supplemental heat in the soil. Soil temperature is important for strawberry growth, affecting root length, production is presented here. Although the basic high tunnel system resulted in positive net returns, the addition of low tunnels within the high tunnel led to a positive increase in net returns for one cultivar, and the additional supplemental heating increased net returns by up to $50 \%$ for both cultivars. Study results find that season extension technologies can successfully increase net returns to strawberry production through early and increased yields, when strawberries are sold primarily through local direct markets.

\section{Materials and Methods}

To complete the economic evaluation of the net returns to each of the three strawberry production season extension methods, data were collected across 3 years (2011-13) of trials on annual hill strawberry production systems at the Utah State University (USU) Greenville Research Farm in North Logan, UT. Costs and returns for one high tunnel strawberry production system were developed and then compared with a high tunnel plus low tunnel system and an in-ground supplemental heating with a high tunnel plus low tunnel system. Two primary strawberry cultivars, Seascape and Chandler, were compared.

For each system, production revenues were divided into two sections: early out-of season strawberries and in-season strawberries. Early yield was calculated as the total mass yield produced before nonprotected field production begins. Early strawberries typically command price premiums over in-season production as a result of increased supplies as field (unprotected) strawberries begin yielding, lowering total price per pound. Test marketing on the USU campus in Logan, UT, concluded that a $\$ 3.30$ per kilogram premium was common for the early, out-of-season strawberries. Additionally, interviews with strawberry growers in Utah concluded that direct market fresh strawberry price averaged $\$ 9.90 / \mathrm{kg}$ for inseason and $\$ 13.20 / \mathrm{kg}$ for early-season strawberries (Day, personal communication, 2013; Meikle, personal communication, 2013; Weeks, personal communication, 2013). These prices were used to calculate the revenues for each system analyzed.

Production supplies were priced based on costs in Logan, UT, and may vary across the region. Plug plants are not commercially available in the Intermountain West and are not amenable to shipping over long distances so must be either produced on-site (Rowley et al., 2010b) or through production contracts with a local nursery. Supplies ordered from online sources will have an additional shipping cost. Labor was priced at $\$ 10.00$ per hour and the quantity of hours required per activity was recorded and averaged over the study period.

Asset depreciation (high tunnel, low tunnel, and heat cables) was calculated using straight line depreciation and assumed no salvage value at the end of the useful life. Total cost of investment was divided by 
Table 7. Comparison of supplemental root zone heating at 7 and $15^{\circ} \mathrm{C}$ on 'Seascape' strawberry.

Partial budget comparing 'Seascape' high tunnel + low tunnel strawberry production with and without the use of $7^{\circ} \mathrm{C}$ supplemental heating

\section{Revenues}

Unheated high tunnel

Early strawberries $(101.2 \mathrm{~kg}$ at $\$ 13.20 / \mathrm{kg})$

In-season strawberries $(172.3 \mathrm{~kg}$ at $\$ 9.90 / \mathrm{kg})$

$\$ 1,335.84$

Unheated total

Heated high tunnel + low tunnel

Early strawberries $(103.4 \mathrm{~kg}$ at $\$ 13.20 / \mathrm{kg})$

$\$ 1,705.77$

$\$ 3,041.61$

In-season strawberries $(221.4 \mathrm{~kg}$ at $\$ 9.90 / \mathrm{kg}$ )

$\$ 1,364.88$

Heating total

$\$ 2,191.86$

Costs

Added costs of low tunnel ${ }^{2}$

Added costs of heating material ${ }^{z}$

$\$ 3,556.74$

Resulting change in net income

Difference in revenue

$\$ 192.47$

$\$ 228.79$

Difference in costs

$\$ 515.13$

$\$(421.26)$

Total change

$\$ 93.87$

Partial budget comparing 'Seascape' high tunnel + low tunnel strawberry production with and without the use of $15^{\circ} \mathrm{C}$ supplemental heating

Revenues

Unheated high tunnel

Early strawberries $(101.2 \mathrm{~kg}$ at $\$ 13.20 / \mathrm{kg})$

In-season strawberries $(172.3 \mathrm{~kg}$ at $\$ 9.90 / \mathrm{kg})$

$\$ 1,335.84$

Unheated total

Heated high tunnel + low tunnel

Early strawberries $(135.5 \mathrm{~kg}$ at $\$ 13.20 / \mathrm{kg})$

In-season strawberries $(211.9 \mathrm{~kg}$ at $\$ 9.90 / \mathrm{kg})$

Heating total

Costs

Added costs of low tunnel ${ }^{z}$

Added costs of heating material ${ }^{2}$

$\$ 3,041.61$

Resulting change in net income

Difference in revenue

Difference in costs

$\$ 1,788.60$

$\$ 2,097.81$

$\$ 3,886.41$

$\$ 192.47$

$\$ 332.95$

$\$ 844.80$

$\$(525.42)$

Total change

$\$ 319.38$

${ }^{2}$ See Table 8 for breakdown of material costs.

Table 8. Annual and depreciation costs for low tunnel and supplemental heating materials.

\begin{tabular}{|c|c|c|c|c|c|}
\hline & Units & $\begin{array}{c}\text { Useful } \\
\text { life (years) }\end{array}$ & Quantity & Unit cost & Total \\
\hline \multicolumn{6}{|l|}{ Low tunnel-depreciation expense } \\
\hline $3-\mathrm{m}$ low tunnel supports ( $1.3 \mathrm{~cm}$ conduit) & Each & 6 & 30 & $\$ 1.65$ & $\$ 49.50$ \\
\hline 5-cm binder clips & Box of 60 & 6 & 1 & $\$ 10.00$ & $\$ 10.00$ \\
\hline $1.3-\mathrm{cm} \times 61-\mathrm{cm}$ rebar & Each & 6 & 60 & $\$ 1.55$ & $\$ 93.00$ \\
\hline Depreciation total & & & & & $\$ \overline{152.50}$ \\
\hline Total annual depreciation cost of low tunnel & & & & & $\$ 25.42$ \\
\hline \multicolumn{6}{|l|}{ Low tunnel-annual expense } \\
\hline 2-mil plastic for low tunnels & \multicolumn{2}{|c|}{$3-\mathrm{m} \times 30.5-\mathrm{m}$ sheet } & 3 & $\$ 27.00$ & $\$ 81.00$ \\
\hline 305-m bailing twine & \multicolumn{2}{|l|}{ Each } & 1 & $\$ 8.55$ & $\$ 8.55$ \\
\hline Installation and removal & \multicolumn{2}{|l|}{ Labor hours } & 7.75 & $\$ 10.00$ & $\$ 77.50$ \\
\hline Annual expense total & & & & & $\$ \overline{167.05}$ \\
\hline Total low tunnel cost & & & & & $\$ \$ 192.47$ \\
\hline \multicolumn{6}{|l|}{ Additional heating —depreciation expenses } \\
\hline Cables (76 m) & Each & 3 & 6 & $\$ 154.27$ & $\$ 925.62$ \\
\hline Thermostat & Each & 6 & 1 & $\$ 89.95$ & $\$ 89.95$ \\
\hline Extension cord $(6.1 \mathrm{~m})$ & Each & 6 & 1 & $\$ 7.98$ & $\$ 7.98$ \\
\hline Additional heating total & & & & & $\$ 1,0 \overline{23.55}$ \\
\hline \multicolumn{5}{|c|}{ Total annual depreciation cost of additional heating } & $\$ 170.59$ \\
\hline \multicolumn{6}{|l|}{ Additional heating - annual expense } \\
\hline Installation and removal & Labor hours & & 3.5 & $\$ 10.00$ & $\$ 35.00$ \\
\hline Electricity $\left(7^{\circ} \mathrm{C}\right.$ amount $)$ & & & & & $\$ 23.20$ \\
\hline Electricity $\left(15^{\circ} \mathrm{C}\right.$ amount $)$ & & & & & $\$ 127.36$ \\
\hline $7^{\circ} \mathrm{C}$ annual expense & & & & & $\$ 58.20$ \\
\hline $15^{\circ} \mathrm{C}$ annual expense & & & & & $\$ 162.36$ \\
\hline Total additional heating cost $\left(7^{\circ} \mathrm{C}\right)$ & & & & & $\$ 228.79$ \\
\hline Total additional heating cost $\left(15^{\circ} \mathrm{C}\right)$ & & & & & $\$ 332.95$ \\
\hline
\end{tabular}

number of years the asset is assumed to be useful resulting in the annual depreciation cost. High tunnel useful life is 6 years and the initial cost of the high tunnel was based on the low-cost high tunnel design used at Utah State University (Black et al., 2008).

Low tunnel and in-ground supplemental heating cost were also calculated based on low tunnels and heat cables used at the Greenville Research Farm (Maughan, 2013). Low tunnels were constructed $\approx 1$ Nov. using $1.3-\mathrm{cm}$ diameter conduit pipe. The conduit was bent in two places to form a square arch and placed over the strawberry beds $\approx 76 \mathrm{~cm}$ wide and $38 \mathrm{~cm}$ tall. Clear, 2-mil construction-grade plastic was placed over the conduit to form the low tunnels. In-ground supplemental heating was done with heavy duty electric heating cables (Wrap-On Company Inc., Bedford Pak, IL) that were buried $\approx 3 \mathrm{~cm}$ below the soil surface of the raised bed in a serpentine pattern and secured with landscape fabric pins. Strawberry plants were placed in between heat cables so the heat cable ran along both sides of the plant, $\approx 5 \mathrm{~cm}$ away from the plant. Cables were activated to heat when soil temperature dropped below 7 or $15{ }^{\circ} \mathrm{C}$, depending on the plot. To monitor electrical use, thermostats were attached to a watt meter (Kill-a-Watt; P3 International, New York, NY). Each heated row (whether 7 or $15^{\circ} \mathrm{C}$ ) was covered with a high tunnel plus low tunnel.

\section{Results and Discussion}

High tunnel only. The cost and returns to strawberry production for one unheated high tunnel are shown in Table 1 and were adapted from an earlier study (Rowley et al., 2010c). The estimated net income per 29-m high tunnel was $\$ 1,943.57$ or $\$ 15,548.56$ per hectare (Ward et al., 2011) when the total production was averaged over 3 years. Plants are fall-planted into raised beds covered with plastic mulch, cared for over the winter, and the plants produce in the spring and are removed in mid-July. Over the three seasons, the field production season began between 1 May and 12 May, whereas high tunnel production began in late March/early April Early production ranged from 0.23 to 0.41 $\mathrm{kg} /$ plant as shown in Figure 2 and early production constituted $44 \%$ of total annual production. Depreciation costs for a high tunnel are detailed in Table 2.

High tunnels vs. high tunnel plus low tunnel. A comparison of the costs and returns of a high tunnel only system and a high tunnel plus low tunnel system was prepared for two cultivars, Seascape (Table 3) and Chandler (Table 4). 'Seascape' is a day-neutral strawberry, meaning it initiates flower buds throughout the growing season regardless of the daylength as long as temperatures are below $22^{\circ} \mathrm{C}$ (Durner et al., 1984). 'Chandler' is a June-bearing strawberry. June-bearing plants are facultative short-day plants, meaning they will initiate flower buds either under short-day conditions (less than $14 \mathrm{~h}$ ) or when temperatures are less than $15^{\circ} \mathrm{F}$ (Strik, 1984). 
Table 9. Effect of supplemental heating on the first day of harvest, 2012.

\begin{tabular}{llr}
\hline & \multicolumn{1}{c}{ Treatment } & $\begin{array}{r}\text { First day } \\
\text { of harvest }\end{array}$ \\
\hline Chandler & High tunnel & 20 Apr. \\
& High tunnel + low tunnel & 10 Apr. \\
& $7{ }^{\circ} \mathrm{C}+$ high tunnel + low tunnel & 8 Mr. \\
& $15^{\circ} \mathrm{C}+$ high tunnel + low tunnel & 17 Feb. \\
& & 28 Mar. \\
Seascape & High tunnel & 23 Mar. \\
& High tunnel + low tunnel & 24 Feb. \\
& $7^{\circ} \mathrm{C}+$ high tunnel + low tunnel & 17 Feb. \\
\hline
\end{tabular}

Yield per plant used for the high tunnel only was a 3-year average and yield per plant for the high tunnel plus low tunnel system was based off of 2012 data only because 2013 yields were severely limited as a result of environmental factors. The early yields used for comparison purposes in Tables 3 and 4 were 101.2 and $169.6 \mathrm{~kg}$ per high tunnel for 'Seascape' and 'Chandler', respectively. In-season yields were 172.3 and $214.4 \mathrm{~kg}$ per high tunnel for 'Seascape' and 'Chandler', respectively. For 'Seascape', the high tunnel plus low tunnel system had a $\$ 1101.46$ per 29-m high tunnel higher net income over the high tunnel only. However, the 'Chandler' high tunnel plus low tunnel system return was less than the high tunnel only return by \$579.56.

High tunnel vs. heated high tunnel plus low tunnel. A comparison of the cost and returns of an unheated high tunnel to a high tunnel plus low tunnel with in-ground supplemental heating was prepared. Two soil temperatures, 7 and $15{ }^{\circ} \mathrm{C}$, were evaluated. Again, the yield per plant for the high tunnel only was averaged over 3 years (2011-12) and yield per plant for heated treatments was based on 2012 data only (Table 5). Early yields were defined as production that occurred before unprotected outside strawberry production began (on 22 May). Early yield typically commands a price premium of $\$ 3.30$ per kilogram. In-season yield was considered all strawberry production that occurred during the unprotected outside the production season (after 22 May).

For both cultivars and both heating levels ( 7 and $15^{\circ} \mathrm{C}$ ), net income was increased with the application of supplemental heating over the high tunnel alone. The increase over the high tunnel only treatments was more dramatic for 'Chandler' than 'Seascape' (Tables 6 and 7, respectively). Although the 'Seascape' heat treatments were numerically lower than the high tunnel plus low tunnel treatment, as a result of high variability, they were not significantly different from each other. The addition of $7{ }^{\circ} \mathrm{C}$ heating resulted in a $\$ 940.32$ higher net income than the high tunnel only system for 'Chandler' and a $\$ 93.87$ higher net income for 'Seascape' per 29-m high tunnel. Supplemental heating set at $15^{\circ} \mathrm{C}$ resulted in a $\$ 1073.10$ increase in net income over the high tunnel only system for 'Chandler' and a $\$ 319.38$ increase for 'Seascape' per 29-m high tunnel. These findings may justify the use of supplemental heating in high tunnel strawberry production in the Intermountain West.

Price per kilogram was based on an equal price throughout the early season. However, heating cables shifted the production season earlier than the high tunnel only and the high tunnel plus low tunnel system by at least 1 month as shown in Table 9. The earliest heat treatments had $\approx 0.23 \mathrm{~kg}$ of fruit per plant produced before the high tunnel only treatments began to yield fruit (Maughan, 2013), which amounted to $28 \%$ of the total season yield. This very early fruit could potentially command even higher price premiums depending on market conditions and further increase the profitability of using supplemental heating.

\section{Conclusions}

This study assessed the economic returns to three season extension methods for strawberry production in the Intermountain West; namely, a high tunnel only system, a high well as targeted, in-ground supplemental heating. Protective systems are often necessary in the Intermountain West to improve yield and increase season length and timing. Variable climactic conditions and significant competition from both domestic production and imports are hindrances to the economic feasibility of current unprotected field strawberry production. Although regional strawberry production is comparatively low on a national level, the increased demand for locally produced foods and corresponding consumer willingness to pay premiums have spurred a renewed interest in strawberry production near urban areas across the region. Thus, evaluating the returns to each system will assist growers in making informed decisions regarding investment in higher-input systems.

Overall, the three season extension methods increased yields and advanced the season and, therefore, net income to strawberry production in the Intermountain West region. Results show that the high tunnel only system is a profitable method of producing strawberries in the Intermountain West when sold through direct market outlets with an estimated net income per 29-m high tunnel of $\$ 1943.57$. Price premiums of $\$ 3.30 / \mathrm{kg}$ for fruit harvested before the typical strawberry season contribute significantly to this profitability. The use of a high tunnel plus low tunnel combination may be justified, depending on tunnel in conjunction with low tunnels as cultivar and year. The addition of low tunnels to a high tunnel was profitable for 'Seascape' but not 'Chandler'.

Additionally, adding low tunnels and supplemental heating at both 7 and $15^{\circ} \mathrm{C}$ can further increase net income, although increase varies by cultivar. Of the two heating temperatures evaluated, the $15{ }^{\circ} \mathrm{C}$ treatments resulted in slightly higher net income than the $7{ }^{\circ} \mathrm{C}$ for both cultivars, although the yields were not significantly different. The higher heat treatment did, however, move the production season $19 \mathrm{~d}$ earlier than the lower heat treatment for 'Chandler' and $7 \mathrm{~d}$ earlier for 'Seascape'. More dramatically, the $15^{\circ} \mathrm{C}$ heat treatment pushed production 62 and $39 \mathrm{~d}$ earlier than the high tunnel only system for both cultivars. Because the early fruit can be sold for a price premium as a result of lack of competition from domestic producers and imports, the additional heating costs may be justified. Further research evaluating additional cultivars under each of these systems would be beneficial as a result of cultivar variability in the results within this study.

\section{Literature Cited}

Arney, S.E. 1953. Studies of growth and development in the genus Fragaria. I. factors affecting the rate of leaf production in Royal Sovereign strawberry. J. Hort. Sci. 28:73-84.

Black, B., D. Drost, D. Rowley, and R. Heflebower. 2008. Constructing a low-cost high tunnel. Utah Sta. Univ. Ext. Bul. HG/HighTunnels/ 2008-01pr.

Boyce, B.R., A.L. Hazelrigg, and A.W. Linde. 1985. Field evaluation of loss of primary or primary and secondary blossoms on strawberry fruit weight and yield. Adv. in Strawberry Prod. 4:32-33.

Carlen, C., A.M. Potel, and A. Ancay. 2009. Photosynthetic response of strawberry leaves to changing temperatures. Acta Hort. 838:7376.

Curtis, K. 2014. Characterizing the face and value of the 'Buy Local' movement. Utah Sta. Univ. Bul. AppliedEconomics/2014-03pr.

Curtis, K.R., I. Yeager, B. Black, D. Drost, and R. Ward. 2014. Market and pricing potential for extended season fresh produce sales: An Intermountain West example. J. Food Distrib. Res. 45:46-65.

Darrow, G.M. and G.F. Waldo. 1934. Responses of strawberry varieties and species to duration of the daily light period. USDA Tech. Bul. 453.

Durner, E.F., J.A. Barden, D.G. Himmelrick, and E.B. Poling. 1984. Photoperiod and temperature effects on flower and runner development in dayneutral, Junebearing, and everbearing strawberries. J. Amer. Soc. Hort. Sci. 109:396-400.

Ernst, T., S.D. Rowley, B.L. Black, and T.R. Roper. 2012. Reviewing potential local fruit markets: A Utah case study. J. Amer. Pomol. Soc. 66:16-22.

Foord, K. 2004. High tunnel marketing and economics. Regents of the Univ. of Minn. Bul. M1218.

Galletta, G.J. and D.G. Himmelrick. 1990. Small fruit crop management, p. 83-156. In: Strawberry management. Prentice Hall, Englewood Cliffs, NJ

Gunter, A., D.D. Thilmany, and M. Sullins. 2012. What is the version of scale efficient: A valuesbased supply chain approach. J. Food Distrib. Res. 43:27-34. 
Hancock, J. and D. Simpson. 1995. Methods of extending the strawberry season in Europe. HortTechnology 5:286-290.

Hummel, R.L. and P.P. Moore. 1997. Freeze resistance of Pacific Northwest strawberry flowers. J. Amer. Soc. Hort. Sci. 122:179-182.

Hutson, S.S., N.L. Barber, F.J. Kenny, K.S. Linsey, D. S. Lumia, and M.A. Maupin. 2005. United States Geological Survey estimated use of water in the United States in 2000. USGS Circular 1267.

Low, S. and S. Vogel. 2011. Direct and intermediated marketing of local foods in the United States. Econ. Res. Rpt. No. (ERR-128). 25 June 2014. <http://www.ers.usda.gov/publications/ err-economic-research-report/err128.aspx $>$.

Maas, J.L. 1998. Compendium of strawberry diseases. 2nd Ed. American Phytopathological Society, APS Press, St. Paul, MN.

Martinez, S., M. Hand, M. Da Pra, S. Pollack, K. Ralston, T. Smith, S. Vogel, S. Clark, L. Lohr, S. Low, and C. Newman. 2010. Local food systems: Concepts, impacts, and issues. U.S. Dept. Agr., Econ. Res. Serv. Rpt 97.

Maughan, T.L. 2013. Optimizing systems for coldclimate strawberry production. MS thesis, Utah State Univ., Logan, UT.

Naeve, L. 2014. Commodity strawberry profile. Publ. of the Agr. Mktg. Resource Ctr. 25 June 2014.
$<$ http://www.agmrc.org/commodities__products/ fruits/strawberries/commodity-strawberryprofile/>.

Rowley, D., B.L. Black, and D. Drost. 2010a. Early-season extension using June-bearing 'Chandler' strawberry in high-elevation high tunnels. HortScience 45:1464-1469.

Rowley, D., B.L. Black, and D. Drost. 2010 b. Strawberry plug plant production. Utah Sta. Univ. Ext. Bul. Horticulture/Fruit/2010-01pr.

Rowley, D., B. Black, and D. Feuz. 2010c. High Tunnel June-bearing strawberry budget 2010: Based on a $14^{\prime} \times 96^{\prime}$ high tunnel. 2010 Utah Agriculture Statistics and Utah Dept. of Ag. and Food Annu. Rpt. p. 94.

Rowley, D.R. 2010. Season extension of strawberry and raspberry production using high tunnels. MS thesis, Utah State Univ., Logan, UT.

Rykbost, K.A., L. Boersma, H.J. Mack, and W.E. Schmisseur. 1975. Yield response to soil warming: Vegetable crops. Agron. J. 67:738-743.

Strik, B.C. 1984. Flower bud initiation in strawberry cultivars. Fruit Var. J. 39:5-9.

U.S. Department of Agriculture: Agricultural Marketing Service. 2014. National count of farmers market directory listing graph: 1994-2014. 20 Nov. 2014. <http://www.ams.usda.gov/AMSv1.0/ ams.fetchTemplateData.do?template $=$ TemplateS\&
navID $=$ WholesaleandFarmersMarkets\&left $\mathrm{Nav}=$ WholesaleandFarmersMarkets\&page $=$ WFMFarmersMarketGrowth\&description= Farmers\%20Market $\% 20$ Growth\&acct= frmrdirmkt $>$.

U.S. Department of Agriculture: Economic Research Service. 2012. U.S. supply and utilization of fresh-market strawberries, 1970 2012. 25 June 2014. <http://usda.mannlib. cornell.edu/MannUsda/viewDocumentInfo. do? documentID $=1381>$.

Ward, R., D. Drost, and A. Whyte. 2011. Assessing profitability of selected specialty crops grown in high tunnels. J. of Agribusiness 29:41-58.

Wien, H.C., J.E. Reid, C. Rasmussen, and M.D. Orzolek. 2008. Use of low tunnels to improve plant growth in high tunnels. 9 July 2012. $<$ http://www.hort.cornell.edu/hightunnel/about/ research/general/USEOFLOWTUNNELSarticle 2008.pdf $>$.

Wu, F., Z. Guan, and A. Whidden. 2012. Strawberry industry overview and outlook. University of Fla. pub. 25 June 2014. <http://www.fred.ifas. ufl.edu/pdf/webinar/Strawberry.pdf $>$.

Yeager, I. 2013. Marketing strategies for small scale producers. MS thesis, Utah State Univ. Logan, UT. 